\title{
KORELASI BIMBINGAN BELAJAR SEBAGAI ALTERNATIF BELAJAR DI LUAR SEKOLAH DENGAN PRESTASI BELAJAR PESERTA DIDIK KELAS VIII SMP NEGERI 3 BELITANG MADANG RAYA
}

\author{
Sigit Priyono ${ }^{1}$ \\ ${ }^{1}$ STKIP Nurul Huda Sukaraja \\ "E-mail: E-mail: sigitpriyono@stkipnurulhuda.ac.id
}

\begin{abstract}
Abstrak: Penelitian ini bertujuan mendeskripsikan secara objektif tentang korelasi bimbingan belajar sebagai alternatif belajar di luar sekolah dengan prestasi belajar peserta didik. Penelitian ini menggunakan metode deskriptif kuantitatif dengan jenis korelasional. Teknik pengumpulan data menggunakan angket dan dokumentasi. Hasil analisis pengolahan data penelitian menunjukkan adanya hubungan yang signifikan antara bimbingan belajar sebagai alternatif belajar di luar sekolah dengan prestasi peserta didik. Berdasarkan uji hipotesis, uji statistik menggunakan rumus $t$ dan didapat bahwa nilai $t$ hitung lebih besar dari nilai $t$ tabel, yaitu 11,518 $\geq 1,703$. Nilai dari regresi sederhana yaitu $\bar{Y}=28,625+0,664 \mathrm{X}$. Hal ini berarti semakin baik bimbingan belajar sebagai alternatif belajar di luar sekolah dilaksanakan maka akan semakin meningkat pula prestasi peserta didik kelas VIII di SMP Negeri 3 Belitang Madang Raya.
\end{abstract}

Kata Kunci: Bimbingan belajar, Prestasi belajar.

\section{PENDAHULUAN}

Pendidikan merupakan satu dari sekian banyak hal yang tidak dapat dipisahkan dalam kehidupan manusia. Melalui pendidikan, seseorang dapat meningkatkan kesejahteraan hidupnya. Pendidikan juga mempunyai peranan penting dalam pembangunan suatu bangsa, karena melalui pendidikan dapat tercipta generasi yang cerdas, terampil, berwawasan dan berkualitas yang diharapkan menjadi generasi penerus-penerus bangsa yang dapat membawa perubahan bangsa menuju kearah yang lebih baik.

Menurut Slameto (2015:2) belajar adalah suatu proses usaha yang dilakukan seseorang untuk memperoleh suatu perubahan tingkah laku yang baru secara keseluruhan, sebagai hasil pengalamannya sendiri dalam interaksi dengan lingkungannya. Menurut Izhar ( 2016:13) belajar adalah proses untuk memperoleh motivasi dalam pengetahuan, keterampilan, kebiasaan dan tingkah laku. Dalam hal ini yang dimaksud belajar adalah usaha untuk mencapai kepandaian atau ilmu yang 
belum dipunyai sebelumnya. Dengan belajar, manusia menjadi tahu, memahami, mengerti, dapat melaksanakan dan memiliki pengetahuan tentang sesuatu.

Menurut Sukardi (2008:2) yang dimaksud dengan bimbingan adalah proses pemberian bantuan yang diberikan kepada seseorang atau sekelompok orang secara terus-menerus dan sistematis oleh pembimbing agar individu atau sekelompok individu menjadi pribadi yang mandiri. Menurut Walgito (2012:52) bimbingan adalah bantuan atau pertolongan yang diberikan kepada individu atau sekelompok individuindividu dalam menghindari atau mengatasi kesulitan-kesulitan di dalam kehidupannya, agar individu atau sekumpulan individu-individu itu dapat mencapai kesejahteraan hidupnya.

Menurut Kholidah (2012:15) bimbingan belajar adalah suatu bantuan dari pembimbing kepada terbimbing (peserta didik) dalam menghadapi dan memecahkan masalah-masalah belajar. Kehadiran bimbingan belajar di luar sekolah merupakan hal yang sangat penting dalam rangka membantu peserta didik agar mampu melakukan penyesuaian akademis, sosial, dan tuntutan psikologis sesuai dengan potensi yang dimilikinya. Pelayanan bimbingan belajar di luar sekolah akan berjalan terpadu dengan program pembelajaran di sekolah.

Menurut Syah (2011:139) prestasi belajar adalah tingkat keberhasilan peserta didik mencapai tujuan yang telah ditetapkan dalam sebuah program. Artinya tingkat keberhasilan peserta didik akan diperoleh setelah ia mencapai tujuan yang telah ditetapkan, tujuan tersebut akan menjadi tolak ukur yang sebenarnya, peserta didik telah berhasil atau belum. Menurut Hamalik (2016:24) berpendapat bahwa prestasi belajar adalah perubahan sikap dan tingkah laku setelah menerima pelajaran atau setelah mempelajari sesuatu. Menurut Azwar (2017:33) prestasi belajar dapat dioperasionalkan dalam bentuk indikator-indikator berupa nilai raport, indeks prestasi studi, angka kelulusan dan predikat keberhasilan.

Observasi awal yang dilakukan di SMP Negeri 3 Belitang Madang Raya memperlihatkan bahwa kelas VIII yang terdiri atas 6 kelas terdapat sekitar $30 \%$ peserta didik yang mengikuti bimbingan belajar di luar sekolah. Jumlah peserta didik yang tidak sedikit apalagi dengan jumlah peserta didik sekitar 28-29 orang per kelas. Tidak hanya itu, di SMP Negeri 3 Belitang Madang Raya juga lebih tinggi tingkat keikutsertaan peserta didik terhadap lembaga bimbingan belajar di luar sekolah. Selain itu, peserta didik kelas VIII SMP Negeri 3 Belitang Madang Raya beranggapan 


\section{KORELASI BIMBINGAN BELAJAR SEBAGAI ALTERNATIF BELAJAR \\ DI LUAR SEKOLAH DENGAN PRESTASI BELAJAR PESERTA DIDIK KELAS VIII SMP NEGERI 3 BELITANG MADANG RAYA}

bahwa dengan mengikuti bimbingan belajar di luar sekolah dapat meningkatkan percaya diri dalam kegiatan belajar dan merasa yakin akan mampu mempertahankan maupun meningkatkan prestasi belajar di sekolah.

SMP Negeri 3 Belitang Madang Raya memiliki salah satu misi yaitu meningkatkan efektifitas pembelajaran dan bimbingan serta meningkatkan prestasi akademik dan non akademik mendorong banyak peserta didik yang termotivasi untuk mengikuti bimbingan belajar di luar sekolah, serta banyaknya peserta didik yang mengalami kesulitan dalam belajar di sekolah. Ada beberapa jenis bimbingan belajar yang diikuti peserta didik seperti lembaga bimbingan swasta, ekstrakulikuler, bimbingan belajar dengan guru di luar sekolah dan les privat di rumah.

Adapun tujuan dalam penelitian ini secara umumnya untuk mengetahui adanya hubungan bimbingan belajar sebagai alternatif belajar di luar sekolah dengan prestasi belajar peserta didik VIII SMP Negeri 3 Belitang Madang Raya.

Salah satu upaya untuk meningkatkan prestasi yaitu dengan memberikan bimbingan belajar. Pelayanan bimbingan yang dapat membantu perkembangan peserta didik, meliputi bidang; bimbingan agama, bimbingan pribadi, bimbingan sosial, bimbingan belajar dan ekstrakurikuler. Selanjutnya salah satu bimbingan yang membantu peserta didik mengembangkan diri berkenaan dengan sikap dan kebiasaan belajar untuk menguasai pengetahuan dan keterampilan adalah bimbingan belajar.

\section{METODE}

Penelitian ini termasuk penelitian deskriptif kuantitatif dengan jenis penelitian korelasional (Arikunto : 2014). Teknik pengumpulan data pada penelitian ini adalah dengan cara membagikan angket kepada peserta didik dan dokumentasi untuk mengumpulkan data berupa nilai raport peserta didik. Analisis data yang digunakan dalam penelitian ini menggunakan analisis deskripsi (sugiyono: 2015).. Sebelum uji hipotesis peneliti melakukan analisis regresi sederhana yang dibantu oleh applikasi SPSS. Selanjutnya melakukan uji hipotesis dengan menggunakan uji t.

\section{HASIL DAN PEMBAHASAN}




\section{Hasil}

a) Hasil Data Bimbingan Belajar

Dalam penelitian ini ada hasil analisis deskripsi data bimbingan belajar cukup baik, karena $41,38 \%$ responden dengan jumlah 12 peserta didik berada di dalam kategori tinggi. Rincian hasilnya dapat dilihat dari gambar diagram pie di bawah ini:

\section{Bimbingan Belajar}

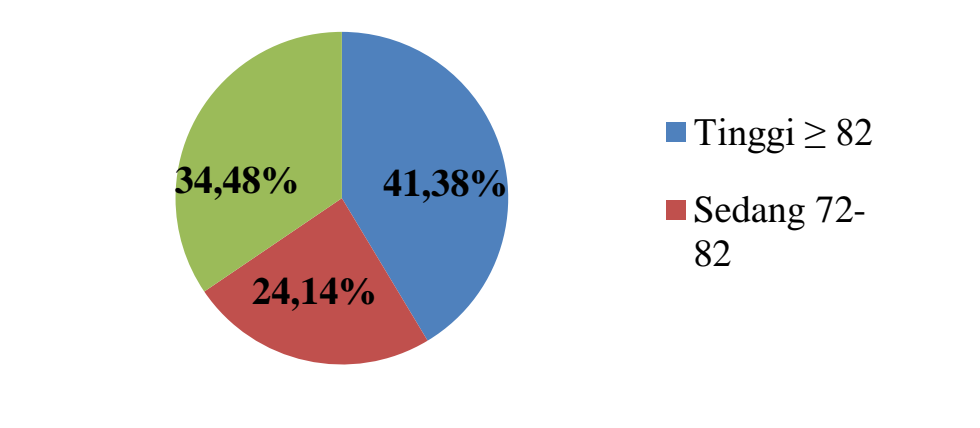

Gambar 1. Diagram Pie Bimbingan Belajar

Dari gambar sebelumnya maka dapat dilihat bahwa Responden di kategori rendah sebanyak $34,48 \%$ (10 peserta didik), dan di kategori sedang sebanyak $24,14 \%$ (7 peserta didik).

b) Hasil Data Prestasi Belajar

Dalam penelitian ini ada hasil analisis deskripsi data prestasi belajar sudah cukup baik, karena nilai raport semester genap peserta didik kelas VIII.D sudah memenuhi nilai KKM walaupun dari hasil perhitungan persentase menunjukkan 44,83\% responden dengan banyak 13 peserta didik berada di dalam kategori rendah. Rincian hasilnya dapat dilihat dari gambar diagram pie di bawah ini: 


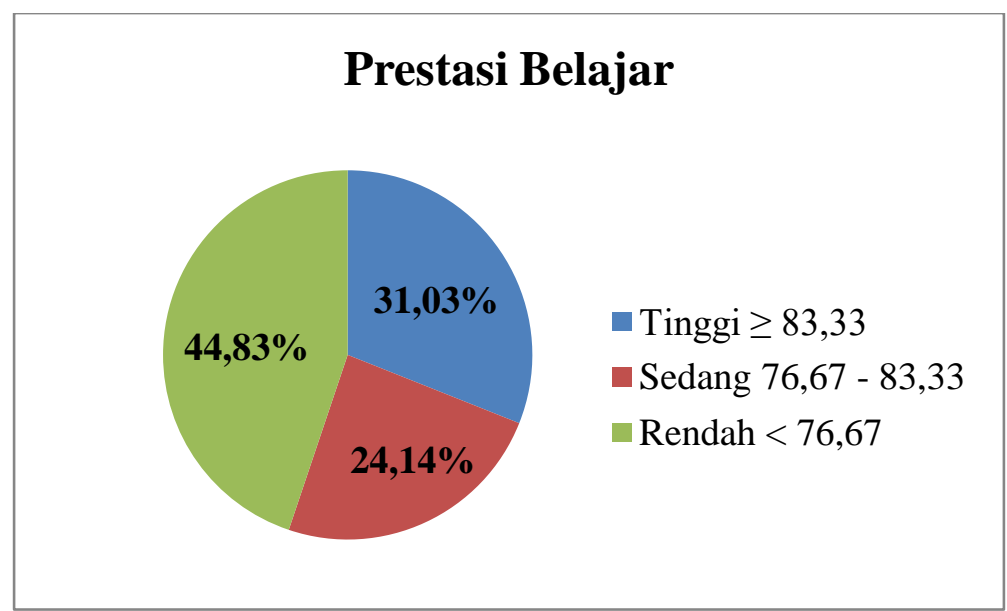

Gambar 2. Diagram Pie Status Sosial Ekonomi Orang Tua

Dari gambar diatas maka dapat dilihat bahwa Responden di kategori sedang sebanyak 24,14\% (7 peseta didik), dan di kategori tinggi sebanyak $31,03 \%$ (9 peserta didik).

c) Uji normalitas data dalam penelitian ini dibantu oleh aplikasi SPSS dengan hasil sebagai berikut:

Tabel 1. Hasil Uji Normalitas

\begin{tabular}{|c|c|c|c|c|}
\hline No & Variabel & $D_{\max }$ & $\mathbf{D}_{\text {tabel }}$ & Kesimpulan \\
\hline 1 & $x$ & 0,106 & 0,246 & Normal \\
\hline 2 & $\mathrm{Y}$ & 0,179 & 0,246 & Normal \\
\hline
\end{tabular}

d) Uji linearitas data dalam penelitian ini dibantu oleh aplikasi SPSS dengan hasil sebagai berikut:

Tabel 2. Hasil Uji Linearitas

\begin{tabular}{|c|c|c|c|c|c|c|c|c|}
\hline \multirow[b]{2}{*}{ No } & \multicolumn{2}{|c|}{ Variabel } & \multirow[b]{2}{*}{ Df } & \multirow[b]{2}{*}{$\boldsymbol{F}_{\text {hitung }}$} & \multirow[b]{2}{*}{$\mathbf{F}_{\text {tabel }}$} & \multirow[b]{2}{*}{ Sig } & \multirow{2}{*}{$\begin{array}{l}\text { Taraf } \\
\text { Sig }\end{array}$} & \multirow[b]{2}{*}{ Ket } \\
\hline & Bebas & Terikat & & & & & & \\
\hline 1 & $X$ & $\mathrm{Y}$ & $17: 10$ & 0.959 & 2,812 & 0.548 & 0,05 & Linier \\
\hline
\end{tabular}


e) Uji Hipotesis

Rumus yang digunakan dalam uji hipotesis antara $X$ terhadap $Y$ adalah regresi sederhana dengan hasil sebagai berikut:

- Persamaan garis regresinya adalah $\hat{Y}=28,652+0,644 \mathrm{X}$

- Hasil kolerasi yang diperoleh adalah $r_{x y} 0,912 \geq r_{\text {tabel }} 0,367$ yang berarti variabel $X$ berpengaruh positif terhadap variabel $Y$.

- Nilai koefisien penentunya atau pengaruh variabel $X$ terhadap $Y$ sebesar $83,1 \%$ sedangkan $16,9 \%$ dipengaruhi oleh variabel lain yang tidak diteliti.

- Hasil uji t disini menunjukkan $t_{\text {hitung }} 11,518 \geq t_{\text {tabel }} 1,703$ sehingga $H_{a}$ diterima dan $\mathrm{H}_{0}$ ditolak.

\section{Pembahasan}

Secara umum bimbingan belajar di SMP Negeri 3 Belitang Madang Raya berada pada kategori tinggi, hal tersebut dapat dilihat dari angket yang disebarkan kepada 29 responden. Berdasarkan skor jawaban ada 12 peserta didik $(41,38 \%)$ berada pada kategorisasi yang tinggi, 10 peserta didik $(34,48 \%)$ berada pada kategorisasi yang rendah, dan 7 peserta didik (24,14\%) berada pada kategorisasi yang sedang.

Secara umum prestasi belajar peserta didik di SMP Negeri 3 Belitang Madang Raya dari perhitungan persentase deskriptif dari 29 peserta didik sudah cukup baik, karena dilihat dari nilai raport semester genap peserta didik kelas VIII.D sudah memenuhi nilai KKM walaupun dari hasil perhitungan persentase menunjukkan kategori rendah. Berdasarkan perhitungan persentase tersebut menunjukkan ada 13 peserta didik $(44,83 \%)$ berada pada kategorisasi yang rendah, 9 peserta didik $(31,03 \%)$ berada pada kategorisasi yang tinggi, dan 7 peserta didik $(24,14 \%)$ berada pada kategorisasi yang sedang.

\section{SIMPULAN}

Dari hasil penelitian mengenai hubungan bimbingan belajar sebagai alternatif belajar di luar sekolah dengan prestasi belajar peserta didik kelas VIII SMP Negeri 3 Belitang Madang Raya, dapat disimpulkan sebagai berikut: 
1. Bimbingan belajar sebagai alternatif belajar di luar sekolah yang diadakan di SMP Negeri 3 Belitang Madang Raya sudah cukup baik, hal ini dapat dibuktikan dengan angket yang telah dijawab oleh para peserta didik. Dari hasil perhitungan persentase deskriptif dari 29 peserta didik jawaban untuk angket bimbingan belajar ada 12 peserta didik $(41,38 \%)$ berada dalam kategori tinggi, 10 peserta didik $(34,48 \%)$ berada dalam kategori rendah, sedangkan ada 7 peserta didik $(24,14 \%)$ berada dalam kategori sedang/cukup.

2. Prestasi belajar peserta didik di SMP Negeri 3 Belitang Madang Raya dari 29 peserta didik sudah cukup baik, karena dilihat dari nilai raport semester genap peserta didik kelas VIII.D sudah memenuhi nilai KKM walaupun dari hasil perhitungan persentase menunjukkan kategori rendah. Ada 13 peserta didik $(44,83 \%)$ berada pada kategorisasi rendah, 9 peserta didik $(31,03 \%)$ berada pada kategorisasi tinggi, sedangkan 7 peserta didik (24,14\%) berada pada kategorisasi sedang/cukup. Disimpulkan bahwa peserta didik cenderung menjawab angket bimbingan belajar berada dalam kategori tinggi sedangkan prestasi belajar peserta didik yang didapat dari nilai raport masih tergolong rendah. Berdasarkan hasil uji regresi juga membuktikan bahwa terdapat korelasi atau hubungan yang positif dan signifikan antara bimbingan belajar sebagai alternatif belajar di luar sekolah dengan prestasi belajar peserta didik. Hal ini ditunjukkan dari hasil perhitungan regresi sederhana yaitu $\hat{Y}=28,652+0,644 \mathrm{X}$.

3. Adanya hubungan secara signifikan antara bimbingan belajar sebagai alternatif belajar di luar sekolah dengan prestasi belajar peserta didik kelas VIII SMP Negeri 3 Belitang Madang Raya berdasarkan uji statistik dengan menggunakan rumus $\mathrm{t}$ didapat bahwa nilai $\mathrm{t}$ hitung yang lebih besar dari nilai $\mathrm{t}$ tabel, yaitu $11,518 \geq 1,703$.

\section{UCAPAN TERIMAKASIH}

Penulis mengucapkan banyak terima kasih kepada semua pihak yang telah membantu dari proses awal penulisan hingga bisa terbitnya tulisan ini. Kepada teman dan sahabat yang selalu memberikan dorongan semangat untuk segera membuat tulisan. Kemudian, khsususnya bagi pengelola jurnal UTILITY yang telah bersedia menerbitkan tulisan ini. Terimakasih. 
Sigit Priyono ${ }^{1}$

\section{REFERENSI}

Slameto. (2015). Belajar dan Faktor-Faktor yang Mempengaruhinya. Jakarta: Rineka Cipta.

Idzhar, A. (2016). Peranan guru dalam meningkatkan motivasi belajar siswa. Jurnal office, 2(2), 221-228.

Sukardi, D. K. (2008). Proses Bimbingan dan Konseling Di Sekolah. Jakarta: PT. Rineka Cipta.

Walgito, B. (2010). Bimbingan dan Konseling . Yogyakarta: Andi Offset.

Kholidah, E. N. (2013). Bimbingan dan Konseling Sosial. Yogyakarta: IKAPI.

Syah, M. (2010). Psikologi Belajar . Jakarta: PT. Raja Grafindo Persada Pustaka.

Hamalik, O. (2008). Kurikulum pembelajaran. Jakarta: Sinar Grafika.

Azwar, S. (2011). Tes Prestasi Fungsi dan Pengembangan Pengukuran Prestasi belajar. Yogyakarta: Pustaka Pelajar.

Arikunto, S. (2014). Prosedur Penelitian Suatu Pendekatan Praktik. Jakarta: Rineka Cipta.

Sugiyono. (2015). Metode Penelitian Kuantitatif, Kualitatif, dan R\&D. Bandung : Alfabeta. 